\title{
Computation Error
}

Here from my perch

On the exam room wall,

I am uniquely positioned

To document it all.

My circuits buzz

Beneath my shiny placard;

The proud host of the newest

Electronic medical record.

Your eyes remain

On the glow of my screen

While your patient tries

To be heard and seen.

She seems to know

That you exist in two places:

Half-listening to her,

Half-filling in blank spaces.

In front of me you sit

Rapidly clicking.

At times she waits silent,

The clock loudly ticking.

Your patient struggles

To meet your eyes,

Which now glazed over,

Strain at my font size.

She asks a pointed question;

You finally move to her,

But my screen glow beckons

And it is with me you confer.

I am metal and plastic,

But even I can see

That your patient, exasperated

Regards you quizzically.

Ryan E Childers

Correspondence to Ryan Childers, The Oregon Clinic GI South, 19250 SW 90th Avenue, Tualatin, OR 97062 USA; rchilde@gmail.com

Competing interests None declared.

Provenance and peer review Not commissioned; internally peer reviewed.

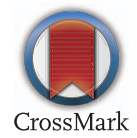

To cite Childers RE. Med Humanit 2017;43:e16.

Published Online First 11 January 2017

Med Humanit 2017;43:e16. doi:10.1136/medhum-2016-011162 